\title{
Adorno's Advice: Minima Moralia and the Critique of Liberalism
}

\author{
JAKOB NORBERG
}

JAKOB NORBERG is assistant professor of German at Duke University. His articles have appeared or are forthcoming in Arcadia, Cultural Critique, German Quarterly, Telos, and other journals.
$\mathrm{T}$ HEODOR W. ADORNO'S MINIMA MORALIA, COMPOSED IN THE United States between 1944 and 1947, entered the West German book market in 1951 and quickly became something of a phenomenon. The volume was reviewed in the major newspapers and on the radio, and, more surprising, it achieved a degree of commercial success. ${ }^{1}$ It did so in part, I would argue, because it offered advice-advice on how to negotiate a range of everyday situations or, more generally, advice on how to live. ${ }^{2}$ Adorno's volume reflected on but also participated in established formats of social communication that made it recognizable as a book of advice, a feature of the text that has been noted (Bernard 17) but far from fully explored. The reflections deal with questions such as the proper choice of gifts, whether to reciprocate or decline conversational invitations on mass transit, and how to live as part of a married couple. These recurring comments on situations of hospitality, sociability, and domesticity claim as much space as the discussions of aesthetics and philosophy, and the attention to the details of daily life is inseparable from morally inflected statements (Jaeggi 115-16). Adorno seems almost to propose a code of behavior in the spheres of privacy and social intercourse with the assured voice of an authority on the overlapping but not coinciding realms of etiquette, civility, and everyday moral issues (Pippin 225). His blocks of text repeatedly culminate in claims about "the only responsible course" ("das Einzige, was sich verantworten läßt" [26;29]), which appeal to the prudence and moral consciousness of the reader. ${ }^{3}$ And at times he even opens a paragraph with a piece of advice directed to a particular segment of the readership: "Advice to intellectuals: let no-one represent you" ("Rat an Intellektuelle: laß dich nicht vertreten" [128; 146]).

(C) 2011 BY THE MODERN LANGUAGE ASSOCIATION OF AMERICA 
Consider the following question, dealt with in the pages of Minima Moralia. How much of what you hear about people should you report to them? You may want to warn friends and acquaintances about resentments that surround them, to give them a better sense of whom to trust, and yet you must proceed with caution. In these situations, you are not simply passing on information; you risk participating in the spread of poison rather than containing its effects. Perhaps you are even attracted by the opportunity to expose a rival and portray yourself as the more reliable friend. Or maybe you too are drawn to the meanness, and something in you wants to get a taste of the maliciousness without having to bear responsibility for it. So what should you do, or when should you tell? "One ought to transmit denigratory remarks only when they relate directly and transparently to shared decisions, to the assessment of people on whom one has to rely, for example in working with them" ("Abfällige Bemerkungen sollte man wiedergeben nur, wenn es unmittelbar und durchsichtig um gemeinsame Entscheidungen, die Beurteilung von Menschen geht, auf die man sich zu verlassen, mit denen man etwa zu arbeiten hat" $[179,203])$. This is good advice, ethically sensitive and pragmatically oriented; it is Adorno's advice.

Adorno, then, offered advice, and he was not the only one doing so in West Germany in the 1950s; in fact, Minima Moralia was part of a national publishing boom in the genre of advice literature. In Horst-Volker Krumrey's quantitative study of trends in conduct literature, broadly defined, from 1870 to 1970 , the decade stands out as a period of increased activity. ${ }^{4}$ The craving for books that offered guidance on social interaction, demeanor, and moral issues is understandable against the background of the economic and political shifts in West Germany around that time, such as the flattening of class distinctions due to increasing prosperity and to longterm collaboration between capital and labor, as well as the desire to overcome or at least cover over the protocols of the Nazi period (Schildt 302). The combination of economic resurgence and attempted cultural restoration resulted in a widespread wish to master forming models of social intercourse and a consequent turn to books that promised to relieve insecurity without reintroducing demands for absolute loyalty or structures of command. East Germany, by contrast, saw no comparable upswing in advice literature, perhaps because of that country's deliberate construction of a nonbourgeois sociopolitical order (Krumrey 25).

After the publication of his reflections in 1951, Adorno remained interested in the character of advice. During a stay in the United States in 1952-53, he analyzed the Los Angeles Times astrology column. The completed study, entitled The Stars down to Earth, is primarily an investigation of irrational elements in a supposedly rational society but includes numerous reflections on the practice of "tendering advice" and its link to questions of authority (48). While the newspaper's astrological counselor derives forecasts from the study of heavenly constellations, Adorno claims that this obviously irrational premise is kept in the background: the "distinctly magical ... authority" of the astrologer is presented as rationally transparent expertise (24). At the same time, the figure of the expert has, in an increasingly complex society reliant on specialized knowledge, morphed into its apparent opposite: "the expert has gradually grown into the magus" (102). The columns address a readership that "seek[s] some advice" (36), which implies that "everyone has to make up his mind" rather than follow oracular pronouncements (28), and yet the position of quasi-magical authority assumed but downplayed by the counselor hollows out advising as a transaction among autonomous persons.

Given Adorno's persistent interest in advice and authority throughout the forties and fifties, it is no surprise that Minima 
Moralia features theoretical remarks on the societal work performed by counseling. In some passages, Adorno indicates that he offers his views on how to approach common situations, conventions, and dilemmas in full awareness of the historically specific presuppositions of advice. The practice of giving and receiving advice, he argues, possesses a distinct class character: “Those who won't take advice can't be helped, the bourgeois used to say, hoping, with advice that costs nothing, to buy themselves out of the obligation to help, and at the same time to gain power over the helpless person who had turned to them" ("Wem nicht zu raten ist, ist nicht zu helfen, sagten die Bürger, die mit dem Rat, der nichts kostet, von der Hilfe sich loskaufen und zugleich Macht über den Erledigten gewinnen wollten, der zu ihnen kam" [136; 154]). If one cannot raise oneself up by acting on sound advice and continuing on the path of selfimprovement, so Adorno's bourgeois figure reasons, then any other kind of support is a waste. Paradoxically, the need for more external assistance than a word or two disqualifies a person from receiving substantial help. The "Bürger" never feels compelled to invest private resources in others without the promise of profit and prefers to withdraw into the less costly role of "catalyst" (Robbins 13). And, one could add, with the self-help books and manuals that make up modern "bibliotherapy" or "minimal contact psychotherapy," advice has been successfully commodified and generates revenue (Bergsma 350, 347).

But Adorno also recognizes the genuine ethical import of (bourgeois) advice: in the act of counseling others on an issue instead of dominating them in the name of protection, one discerns an "appeal to reason" and a faith in the capacity of fellow individuals ("Appell an die Vernunft" [Minima 136; 154]). The adviser seeks to facilitate accomplishments and decisions in a way that testifies to people's need of the greater experience of others but does not negate their individual initiative.
What separates the adviser and the advisee is not a permanent hierarchy of ability or talent but a redeemable lack of crucial information. The recipient may lack experience, knowledge, or material assets but still possess good judgment, and advice is meant to close the gap across which it travels. Ideally, then, advice involves the acknowledgment of interdependence in a way that does not undermine the possibility of self-determination. This makes the practice of advice giving a significant mechanism of knowledge distribution and influence in bourgeois society: the flow of advice makes information, experience, and patterns of reasoning available across boundaries of various kinds without eroding the notion of autonomy on which the self-definition of bourgeois society rests. ${ }^{5}$ In this way, acts of giving advice project and preserve an egalitarian community of independent individuals.

Adorno, however, does not believe in the viability of advice. Whatever good suggestions the reader may find in Minima Moralia, it is framed by repeated, even obsessive, announcements of the end of the bourgeois era as well as of the demise of the selfdetermining subject, the projected recipient of advice. This message is first delivered in the opening paragraph of Adorno's introduction, which states that the ostensibly private domain of the individual subject no longer possesses a reliable integrity but is completely determined by societal forces alien to it. It is doubtful whether the specific vocabulary of personal experience based on everyday interactions can illuminate the greater systemic logic that ultimately shapes and constrains it (Bernstein, Adorno 116-17; Helmstetter $148,153)$, and, in any case, this logic nullifies any attempt by the subject to regain a measure of control. Minima Moralia's concern for the reader's moral orientation and everyday competence, which is implied in the ongoing presentation of advice, is not grounded in a continued belief in the means of the individual subject. The text speaks to issues 
that appear in the individual's frame of attention and comprehension and yet consistently disputes that this is a meaningful realm of action. This contradiction may explain the volume's taxing effect on the reader but also points to the character of Adorno's intervention. Adorno packs a social-theoretical diagnosis into a generic form that is undermined by this very diagnosis. The volume inhabits and violates the conventions of textually mediated advice in order to draw attention to or, better, to organize the experience of the discrepancy between society's logic and the individual's cognitive and pragmatic resources. And it performs this operation in the field of a particular genre for a clearly outlined reason: to deliver a critique of classical liberalism as well as of the totally administered world.

\section{The Critique of Liberal Social Theory}

The problem with Hegel's social theory, Adorno contends in his introduction to $\mathrm{Mi}$ nima Moralia, is that it is stuck in liberal thought. The specifically liberal notion to which Adorno refers is that of a society as a harmonious whole paradoxically arising out of fierce competition among self-interested individuals. If political theorists in the preliberal age tended to equate conflict with disintegration and therefore promote a thick tissue of shared sociomoral commitments, liberals pay attention to the benefits of multiple conflicts and rivalries (Bobbio 22). Without expecting or trying to achieve it, individual agents further the interest of society when they devote themselves to egoistic projects (Bull 35-36). Society does not fall apart because seemingly asocial passions and vices drive individuals; the fissiparous tendencies do not ruin society but instead ensure its development on an aggregate level, at least if one concentrates on economic prosperity (Hirschman 130). This liberal insight into the unintended benefits of competition and strife is famously captured in Adam Smith's notion of the invis- ible hand, but according to Adorno Hegel too tracked the tendency toward integration and mutual advantage that exceeded the limited purposes of the parties (Pfau 86; Vogl 45; Rosen 120-28): "Certainly [Hegel] perceives, with classical economics, that the totality produces and reproduces itself precisely from the interconnection of the antagonistic interests of its members" ("Wohl gewahrt er, mit der klassischen Ökonomik, daß die Totalität selbst aus dem Zusammenhang der antagonistischen Interessen ihrer Mitglieder sich produziert und reproduziert" [Minima 17 ; 15-16]). Operating in a liberal paradigm, Hegel reconstructed how manifold agents who pursue their own ends still produce and compound a complex system of socioeconomic interdependencies without necessarily willing or perceiving it (340; Riedel 89-90, 93). His commitment to liberal thought, then, does not necessarily entail much respect for the horizon of the individual. Liberalism installs individuals as the irreducible elements of society and seeks to remove external constraints to their actions, and yet the model of collectivity that liberal theory propounds is still indifferent to individual subjects' capacity to comprehend their global context.

Adorno presents a twofold objection to Hegel's liberal model of society. On the one hand, Hegel's view of individual subjects' limited understanding of the processes in which they are involved-a legacy of liberalismbetrays a supercilious attitude, or a "patriarchal meagreness" ("altväterliche Kargheit" [Minima 17; 16]). Convinced that individuals' understanding of their society and of the place and significance of their actions in it can never measure up to the theorist-philosopher's insight into laws that govern the whole, Hegel even seems to ally himself philosophically with disregard for the individual, whose freedom and status liberalism supposedly champions: "The dismissive gesture which Hegel ... constantly accords the individual, derives paradoxically from his necessary entanglement 
in liberalistic thinking" ("Die erledigende Gebärde, mit welcher Hegel . . stets wieder das Individuelle traktiert, rührt paradox genug her von seiner notwendigen Befangenheit in liberalistischem Denken" [16-17; 15]). And yet despite this built-in condescension, the image of the individual remains the undisputed and unexamined point of departure for Hegel's theory, in which this figure is pictured as a hardened, strangely decontextualized self. Adorno takes liberal theory to task for being both cold and naive in its conceptualization of the individual: cold because it dismisses the relevance of the individual's experiential horizon and naive because it presupposes the individual's existence as an isolated atom.

Following these objections, Adorno announces a double task: to analyze the socioeconomic constitution of individual subjects rather than take them for granted as the basic units of any social study but to do so without subordinating them so brusquely to the supposedly lawful progression of society as a whole. Adorno sets out to demystify the neatly bounded and independent self by dissolving it back into the play of human interactions and the work of societal forces, but he also withdraws from the notion that the realm of individual experience can never yield any knowledge about the movements of society as a whole or even that individual actions always promote or should promote the assumed development of this whole. Individual experience, Adorno asserts, can be relevant to a theorist of the social world, and not everything that the individual does is entirely subservient or perfectly fitted to the inexorable work of vast collective structures. Yet one can illuminate moments of insight and incongruence without denying the individual subject's social history. Adorno wants to carry out the analytical corrosion of the individual more fully to debunk the myth of the individual's naturalness and yet wants to show how the individual's experience can highlight, and even resist assimilation to, society's development.
But what kind of situation or object of attention would allow Adorno to dismantle the rigid polarity between individual and society? As mentioned above, he repeatedly announces that the overpowering movements of socialization and integration have hollowed out individual subjects. In his view, people are incessantly coerced, bribed, and trained to satisfy the system requirements of compounded market and state structures in a world of tight administration; through close coordination between the state and concentrated capital, coinciding political and economic structures of domination blot out individual agency (Jarvis 57-58). Liberal rhetoric may still speak of autonomy, but the regimentation of all aspects of life in modern societies demonstrates the subordination of the individual subject in the age of technocratic state capitalism. In the phase of the individual subject's diminishing significance, however, become visible the outlines of a more problematic relation between individual and society than was possible in the boundaries of liberal thought: "In the period of his decay, the individual's experience of himself and what he encounters contributes once more to knowledge, which he had merely obscured as long as he continued unshaken to construe himself positively as the dominant category" ("Im Zeitalter seines Zerfalls trägt die Erfahrung des Individuums von sich und dem, was ihm widerfährt, nochmals zu einer Erkenntnis bei, die von ihm bloß verdeckt war, solange er als herrschende Kategorie ungebrochen positiv sich auslegte" [Adorno, Minima 17-18; 16]). The individual subject seems gradually to disappear in a world captured by administration and is hence no longer an unquestionable fact. This development indicates that the emergence of the idea of bounded, autonomous persons depended on socioeconomic conditions that are susceptible to change (Schweppenhäuser 59-62). And yet the still-existing vocabulary of subjective experience, as well as continued endeavors to achieve individual autonomy, exceed the 
needs of the emerging social order. The individual subject no longer stands as a sharply contoured entity but seems rather a remainder from an earlier capitalist stage, and it is in this moment that the individual resists absorption by the socioeconomic system.

Adorno focuses on the shift between two socioeconomic paradigms-classical market liberalism and state capitalism-when the previously taken-for-granted individual subject operating in the realms of domesticity, sociability, and the market has not yet been socialized into a "nullity" ("Nichtigkeit" [Minima $16 ; 14]$ ) by total administration. This is the transitional phase in which the notion of the individual subject reveals itself as a prejudice rather than an invariant reality, but a prejudice somehow obdurate enough to stay on for a moment before its eventual disintegration. To say that a nonpolar relation between individual and society only emerges in the transition between epochs is also to say it only emerges in the passage of time. In the places where Adorno makes a case for the individual as a worthwhile object of reflection, temporal markers pile up: individual experience releases an insight at the point at which the individual subject is "no longer" ("nicht mehr" $[16 ; 14])$ an incontestable reality, or it "temporarily" ("temporär" $[18 ; 16]$ ) becomes a source of understanding of and resistance to the workings of societal forces. Adorno commits himself to the image of the (bourgeois) individual when this figure has slipped into a precarious state, for in this intermediary phase between self-evidence and oblivion, the individual represents a social order that, at least for a moment, lags behind itself and has yet to extinguish completely residues of earlier formations. One social structure is being displaced by an emerging one, but previously hallowed notions, such as that of the autonomous individual, seem to give way a little later than the structural socioeconomic conditions that once facilitated their genesis. This delay constitutes Adorno's critical moment: it allows him to expose the constitution of the individual under particular social circumstances without necessarily disregarding the epistemic worth of this individual's experience.

The preface to Minima Moralia charges Hegel with chilly impatience with the individual's horizon of experience, although on other topics Hegel lingers with the thing under study_-"dwelling upon it" ("bei ihm verweilt" $[16 ; 18])$. The practice of dwelling or lingering (verweilen) turns out to be a key notion for Adorno, insofar as it suggests an enduring focus that alone can trace individual subjects' loss of their scripted roles in the social whole. It is in the process of this loss, Adorno indicates, that the individual exceeds the needs and demands of the emerging order: "In face of the totalitarian unison with which the eradication of difference is proclaimed as a purpose in itself, even part of the social force of liberation may have temporarily withdrawn to the individual sphere. If critical theory lingers there, it is not only with bad conscience" ("Angesichts der totalitären Einigkeit, welche die Ausmerzung der Differenz unmittelbar als Sinn ausschreit, mag temporär etwas sogar von der befreienden gesellschaftlichen Kraft in die Sphäre des Individuellen sich zusammengezogen haben. In ihr verweilt die kritische Theorie nicht nur mit schlechtem Gewissen" [18; 16]).

A more skeptical reader of Minima Moralia may feel that an intensely personal attachment to a past era is noticeable on almost every page (Bernard 9). Yet the bourgeois individuals, who may or may not have populated Adorno's childhood, become theoretically interesting in the process of delayed disintegration that strips them of obvious membership in the current system. A cluster of virtues and ideals, habits, conventions, and shared experiences deserves attention when it no longer is subservient to the dictates of an economic order, for it has then entered a stage of fragile heterogeneity in relation to the changed infrastructure, or become a 
remainder out of place, and thus represents society's moment of self-transcendence in time. Like other twentieth-century theoreticians of "civil society," such as Talcott Parsons and Antonio Gramsci, then, Adorno speaks of a dimension of human sociability irreducible to the logic of market exchanges and to the compulsion of a state apparatus (Arato and Cohen 117-76), but he only does so with the introduction of the factor of historical time: a truly "civil" society is for Adorno necessarily a phenomenon of delay. The civility of civil society is released when this historical formation is in decline. His focus is therefore neither the civil society with its bourgeois agents as conceptualized by Hegel nor the "postcivil condition" in which nobody is educated or expected to assume a fixed identity or character (Hardt 40) but the gradual undoing of the individual subject in the passage in between.

Critique is only possible in the moment of delay, insofar as this delay postpones the full realization of a social totality in which nothing and no one can maintain any distance from the prevailing circumstances. Focusing on verweilen, Adorno indicates that his critique depends on the residual status of that which he concentrates on-the individual subject with its bourgeois background. The social context generates a fading possibility of a "critical stance towards itself," which Adorno takes up and explores (Postone 88). Of course, he could have focused on other historical moments of delay, such as the transition from feudalism to capitalism. But while the bourgeois subject is not the first historical figure with a critical potential, Adorno seems to suggest that it may be the last. He articulates a critique of liberalism, but in the theoretical space where he could have introduced a collective subject committed to the supersession of this ideology, such as the proletariat (Jarvis 54), he chooses to stay behind, to linger, with the bourgeois subject. One looks in vain for an elaborate reflection on politics as the practice of collective self-rule (Wagner 227). Minima
Moralia is not a manifesto that aims to conjure up a latent but not yet fully constituted collectivity (Puchner 31) but, paradoxically, a book of advice for the vanishing individual.

\section{Counseling as Critique}

The preface to Minima Moralia is an entryway into a performance of social philosophy; the outlined critique is inseparable from its enactment in the writing, which deploys genre conventions and the situation of address that they set up. Adorno works in the form of the advice book and takes over its canon of topics, means of formulating problems, and built-in mode of exhortation. At this juncture, we must resume the discussion of the (bourgeois) history and presuppositions of advice-that is, the particular way that advice imagines the relation of the individual to the world, models the exchange between self and other, and attributes significance to conditions and actions.

Adorno speaks of the inability of individual subjects to grasp completely the forces that undermine their status as efficacious agents, and yet he does not for this reason move beyond the limited perspective for the sake of some greater analytic advance as Hegel does, eliciting Adorno's criticism. When Adorno introduces the practice of lingering, he means to stay within the sphere of the individual subject and respect the subject's concerns, despite a theoretically elaborated acquaintance with a context that lies beyond the individual's frame of attention or capacity of imagination. To write in the format of the book of advice is to remain in the subject's area of experience and action at the level of genre, for a book that offers the reader guidance must set up a perspective on the world that is congruent with that of the individual subject (Luhmann 69-73). Such a book's stories and examples of how one can learn to negotiate difficult situations, achieve success, or become a moral being must project strategies plausibly avail- 
able to a single person. A constitutive feature of the practice of advice is to frame problems in such a way that they seem manageable to a resourceful individual. Those who affirm the standard handbook format for its exoteric and democratizing impulse to break down barriers for knowledge acquisition and selfimprovement (Fuller 134-47) and those who criticize it for assigning responsibility to isolated individuals for problems of a socially systemic kind (Robbins 87; McGee 177) agree on this point: the genre trims things down to a scale where individual agency is supposed to become effective.

By locating himself in the social practice of advice, Adorno refuses to move from the scene of the individual subject and thereby fulfills his commitment to lingering. Almost all the entries in Minima Moralia are imbued with an urgent tone that fixes individuals and even demands their unfailing vigilance. At the same time, Adorno does not subscribe to the notion of effective individual action or heroic resistance to the logic of integration; that would be to indulge in illusions. The text robs the reader of the belief inherent to the mode of address of the advice book, namely that pressing problems and moral issues can be adequately grasped and dealt with within the individual's immediate sphere of cognition and influence. It does so by first presenting situations that seem to demand an appropriate response and then subverting various alternative answers until the reader stands before an irresolvable task. Adorno provides lists of practices and positions to be avoided without supplementing them with positive advice in order to bring out the discrepancy between socially generated problems and the therapeutic resources at the individual's disposal. The individual remains the addressee of the texts, but the relentlessly accumulating statements make clear that the room for meaningful individual action has dwindled to nothing. The picture of the current state of alienation, which puts everyone at the mercy of uncontrollable and intolerable conditions, reaches the reader as a duty to be assumed. This textual strategy finds its final expression in one-liners, which tend to conclude the passages: "There is no way out of entanglement" ("Es gibt aus der Verstricktheit keinen Ausweg" [27; 29]), or "Wrong life cannot be lived rightly" ("Es gibt kein richtiges Leben im falschen" [39; 43]). No action can follow upon such maxims. Without releasing the reader from the commitment to lead a responsible life, then, Adorno methodically hollows out the promise of an easily available position.

This rhetoric is put into practice in a note on intellectuals entitled "Little Hans":

The intellectual, particularly when philosophically inclined, is cut off from practical life: revulsion from it has driven him to concern himself with so-called things of the mind. But material practice is not only the pre-condition of his existence, it is basic to the world which he criticizes in his work. If he knows nothing of this basis, he shoots into thin air. He is confronted with the choice of informing himself or turning his back on what he hates. If he chooses the former, he does violence to himself, thinks against his impulses and in addition runs the risk of sinking to the level of what he is dealing with, for economics is no joke, and merely to understand it one has to "think economically." If, however, he has no truck with it, he hypostasizes as an absolute his intellect, which has only formed through contact with economic reality and abstract exchange relations, and which can become intellect solely by reflecting on its own conditions. ... Intellectual business is helped, by the isolation of intellect from business, to become a comfortable ideology. This dilemma is communicated to intellectual behavior even in its subtler reactions. Only someone who keeps himself in some measure pure has hatred, nerves, freedom and mobility enough to oppose the world, but just because the illusion of purity-for he lives as a "third person"-he allows the world to triumph not merely externally, but in his innermost thoughts. Anyone, however, who 
knows the business too well forgets to know it for what it is; his capacity for differentiation deserts him, and as the others are threatened by a fetishism of culture, so is he by a lapse into barbarism.... Whatever the intellectual does, is wrong. He experiences drastically and vitally the ignominious choice that late capitalism secretly presents to all its dependants: to become one more grown-up, or to remain a child.

(132-33)

Der Intellektuelle, und gar der philosophisch gerichtete, ist von der materiellen Praxis abgeschnitten: der Ekel vor ihr trieb ihn zur Befassung mit den sogennanten geistigen Dingen. Aber die materielle Praxis ist nicht nur die Voraussetzung seiner eigenen Existenz, sondern liegt auch auf dem Grunde der Welt, mit deren Kritik seine Arbeit zusammenfällt. Weiß er nichts von der Basis, so zielt er ins Leere. Er steht vor der Wahl, sich zu informieren oder dem Verhaßten den Rücken zu kehren. Informiert er sich, so tut er sich Gewalt an, denkt gegen seine Impulse und ist obendrein in Gefahr, selber so gemein zu werden wie das, womit er sich abgibt, denn die Ökonomie duldet keinen Spaß, und wer sie auch nur verstehen will, muß "ökonomisch denken". Läßt er sich aber nicht darauf ein, so hypostasiert er seinen an der ökonomischen Realität, dem abstrakten Tauschverhältnis überhaupt erst gebildeten Geist als Absolutes, während er zum Geist werden könnte einzig in der Besinnung auf die eigene Bedingtheit. ... Dem Geistesgeschäft verhilft die Isolierung des Geistes vom Geschäft zur bequemen Ideologie. Das Dilemma teilt sich den intellektuellen Verhaltensweisen bis in die subtilsten Reaktionen hinein mit. Nur wer gewissermaßen sich rein erhält, hat $\mathrm{Ha}$, Nerven, Freiheit und Beweglichkeit genug, der Welt zu widerstehen, aber gerade vermöge der Illusion der Reinheit - denn der lebt als "dritte Person" - läßt er die Welt nicht draußen bloß, sondern noch im Innersten seiner Gedanken triumphieren. Wer aber das Getriebe allzu gut kennt, verlernt darüber zu erkennen; ihm schwinden die Fähigkeiten der Differenz, und wie den anderen der Fetischismus der Kultur, so bedroht ihn der Rückfall in die Barbarei.
... Wie der Intellektuelle es macht, macht er es falsch. Er erfährt drastisch, als Lebensfrage die schmähliche Alternative, vor welche insgeheim der späte Kapitalismus all seine Angehörigen stellt: auch ein Erwachsener zu werden oder ein Kind zu bleiben.

$(150-51)$

The aphorism points to two alternative paths: intellectuals may insist on their autonomy or recognize their dependence on material practice. In the manner of a careful, deliberative process, available options are weighed and their divergent consequences drawn out: the passage foregrounds a "dilemma" or a situation of "choice" and proceeds by reviewing the effects of the chosen approaches ("If he knows nothing of this basis," "If he chooses the former," "If, however, he has no truck with it"). Yet the point is hardly to present a ranking of measures that could ultimately guide the decision of the reader but rather to drive home that the intellectual either falls for the illusions of autonomy or experiences the brutalizing effects of recognized dependence, both of which are degrading. The text does not abstain from the modality of advice so much as it seeks to show how any advice has become impossible. Adorno explores the conditions of perennial immaturity and oversocialization but refuses to admit that one could still be in some way preferable to the other. There is no third option, and the text suppresses the notion of a lesser evil, which would still allow for the activity of counseling; when two (and only two) possible alternatives are equally bad, there can be no space for advice. ${ }^{6}$ In the above passage, then, the "advice to intellectuals" of which Adorno speaks in another entry appears only as a mirage. The aphorism goes through the motions of scrutinizing alternatives without allowing for a resolution. Despite the repeated references to "choice," it turns out that there really is none, for every action and attitude is "wrong."

Minima Moralia is designed to aggravate rather than alleviate perplexity. Not unsur- 
prisingly, commentators have, throughout Minima Moralia's reception history, criticized Adorno for pushing readers into a state of tense paralysis (Bernstein, Adorno 57). His bleak vision of society, or rather his bleak vision of society coupled with his continued appeal to individual agency, produces nothing but despair. Balking at the negativity of Adorno's position, an early reviewer recommends Minima Moralia to readers with an imperturbable religious faith, by which he probably means readers strong enough to ignore Adorno's message completely (Demirovic 548). What such critical voices neglect is that Adorno partly wrote his book to counter the "can-do spirit of the achievement expert" in the growing self-improvement and self-help literature for careerists (Lizza 43). The gesture of Minima Moralia becomes visible against the backdrop of this "do-it-yourself" trend, on which Adorno himself commented (Critical Models 291): heading into an era of greater prosperity, books of advice in the two nations he knew well-West Germany and the United States-tied models of self-mastery to the prospect of a speedy career. More generally, the attraction of books that promise greater agency and influence lies not only in the hope for future accomplishments but perhaps also in the power rush that the mere consumption of them provides. (This notion may account for the current popularity of management books such as Influencer: The Power to Change Anything and similar guides to the supposedly simple art of world domination [Patterson et al.].) Their popularity depends on their evocation of prefabricated fantasies of making it, growing rich, dominating the social surroundings, or, apparently more modestly, soothing oneself. Against the indulgence in such empowerment techniques (Rimke 64), Adorno delivers a book of disempowerment. ${ }^{7}$ A more inspiring account would not have suited Adorno's purposes, because a manual for self-regulation in the service of success would only have consolidated the im- age of the forceful individual agent, who is in fact locked into schemes of domination.

Yet Adorno's motivation for publishing a paralyzing book of advice must ultimately be placed in the frame of his scrutiny of liberal thought. In the preface, Adorno claims that the individual's experience in and of the "period of his decay" ("Zeitalter seines Zerfalls" $[17 ; 16])$ yields insights into the violence perpetrated by the integrative mechanisms of a self-maintaining economic system. But he does not simply refer to this process; Minima Moralia constitutes an attempt to draw forth and explore the precise moment of insight. The declared commitment to the disintegrating individual involves a commitment to the individual's locally focused frame of concentration and understanding, which is being overwhelmed. The socioeconomic constitution and conditioning of individual subjects are thus evoked as a lived predicament as Adorno acquaints these subjects with their ongoing destruction. And Adorno accomplishes this by adopting a genre that he understands as ideologically aligned with bourgeois values and then pushing that genre to the point where its premises become untenable. He not only speaks about the conception of the robust individual subject able to turn advice into real action; he appeals to the reader as such an individual subject while simultaneously revealing this conception to be an impossible, superseded position. Minima Moralia neither allows for passivity nor promises achievement, and in this way it seeks to halt the individual subject's disintegration without reinstating him or her.

By conjuring up the prospect of successful self-regulation, Adorno tries to stimulate not readers' self-confidence but rather their lucid understanding of their utter helplessness. The devastating and disempowering effect of the text necessarily relies on a prior promise of empowerment (Benjamin 58). The volume elicits and then immediately disappoints the hope of mastery, to let the reader not retreat 
from but rather stand exposed to a social reality that is beyond control. It feeds aspirations, but only to prolong the moment of tension that constitutes the bourgeois subject's peculiar afterlife. In this way, Adorno tries to bring about or lengthen the duration of the delay of which he speaks, namely the delayed exit of the individual subject, who alone can present heterogeneity in the prevailing system. He does more than comment on the unfitness and veritable sacrifice of the individual subject to the demands of systemic laws-he seeks to occupy and convey this unfitness as it plays out, in the form of the incongruence between capacity and problem, perception and event. Perhaps nostalgia ("Things used to be better") or despair ("There is nothing you can do") must be seen as occasional side effects of a structure in which the heterogeneity between system and remainder can assume the form of discordant experience.

Adorno's appropriation of institutional formats of communication has a definite rhetorical purpose: he uses literary means to shift the way we tend to view our life. ${ }^{8}$ Minima Moralia participates in known discursive formats-giving and taking advice-in order to disclose a world that renders these formats obsolete. When confronting readers with helplessness without letting them withdraw again into comfortable ignorance, Adorno must overcome two related problems or lines of defense. As discussed above, individuals may not be able to grasp the societal logic to which they are subject: the objective and anonymous laws that determine their lives are not necessarily salient to them in their perception of the everyday. Yet Adorno clearly does believe that a theoretical understanding of society is available to any individual (otherwise the book would be impossible) and even holds that references to the great complexity of advanced societies (Kompliziertheit) only serve to screen society's lawlike movements (Philosophische Elemente 73). Knowledge is not impossible, then, but it may well be unbearable, for individual subjects tend to recoil from the recognition of their powerlessness. Adorno notes that people lose sight of that which is permanently out of reach or impervious to change, because the cognition of the objective conditions threatens to become an additional source of suffering and, understandably enough, subjects reduce this burden by means of forgetting and disavowal ("Sociology" 89; Philosophische Elemente 74). Minima Moralia is designed to work against such "adjustments" of projects to actual possibilities (Elster 240): “The almost insoluble task is to let neither the power of others, nor our own powerlessness, stupefy us" ("Die fast unlösbare Aufgabe besteht darin, weder von der Macht der anderen, noch von der eigenen Ohnmacht, sich dumm machen lassen" [Minima 57; 63]). The book does not deny or remove powerlessness but does fight the onset of stupidity as the ultimate way in which individuals participate in their own liquidation.

\section{Society as Experience}

In his lectures on sociology in Frankfurt, Adorno would point out that the science devoted to society, with its double origin in philosophy and technologies of modern governance, maintains an indifference toward the particular individual that is simply the other side of its focus on complex, aggregate phenomena such as institutions and markets. The discipline constitutes itself by bracketing the actions of any individual and simultaneously implies that its object cannot be illuminated from the vantage point of the individual's narrow horizon. With Émile Durkheim, however, Adorno asserts that there is such a thing as an experience of society, although it is necessarily one that hurts. Society appears for individuals as an overwhelming and yet elusive force, or it appears only when they run into innumerable obstacles and frustrations in their attempts to secure a livelihood and are forced to conclude that their 
entire existence is subjected to strangely punitive automatisms: doors close everywhere; everyone they meet says no. Adorno speaks of the "inert mass" ("zähe Masse" [Einleitung 89; my trans.]) that is society to the individual: "Society becomes immediately tangible where it hurts" ("Gesellschaft [wird] unmittelbar da fühlbar ... wo es weh tut" [65; my trans.]).

Minima Moralia hurts, by which I mean that the manipulated generic status of this volume and the rhetorical relentlessness that its manipulation releases are meant to explore society as experience. Adorno's claim that individual experience can still be a site of societal knowledge is as much the project in Minima Moralia as it is the premise: the book tries to organize and induce this experience. It tries to facilitate individual subjects' cognition of their precarious situation, and by means of a complex rhetorical project it also seeks to protract the moment in which a remainder, the vulnerable individual subject, refuses an emerging totalizing system in the passage of time. In Minima Moralia, then, Adorno is not a philosopher who imparts wisdom, and he is not only a philosopher preoccupied with the demise of the individual in the devouring corporative world. He is, or he is also, an author who combines the discrepant approaches of critical social philosophy and advising as a social practice in order to reveal and commemorate, in an experientially accessible manner, the damage being done.

Our task, Adorno writes, is to avoid stupefaction. This amounts to a call to reflection. Thinking alone may seem a feeble, even disappointing, response to intensified repression, and yet it goes against the molding of subjects to fit the organizational needs of society. For Adorno, thinking takes place beyond the subordination of particulars under established concepts, a process through which particularity is squandered rather than preserved (Bernstein, Fate 195-96). In fact, thinking occurs only in and through a commitment to that which escapes conceptu- ality and yet demands our careful (and even loving) attention. Adorno therefore does not believe that we should resist and remodel current society if we attempt to do so under the guidance of a clear vision of another and better society. We should relinquish the attempt to act in the name of anything that possesses a fixed label and is fully conceptualized. Resistance to repression thus lies in the way in which we break away, through genuine thought, from the compulsive erasure of particulars that has become institutional reality in advanced society. By patiently reflecting on what faces submersion because it does not fit the needs and categories of society, on "what yet must pass away" ("was doch vergeht" [122; 138]), Minima Moralia enacts resistance.

\section{Notes}

1. Writing fifty years after its publication, Ulrich Raulff calls Minima Moralia an unlikely book-market success ("buchhändlerischer Erfolg") and speaks of 120,000 copies sold in West Germany (124).

2. The texts in Minima Moralia fit a number of genres: aphorism, emblem, epigram, essay, fragment, miniature, and meditation, to name a few (Richter 2-7; Bernstein, Adorno 356). The standard term is probably Denkbild, or thought image. In his study from 2007, Gerhard Richter defines the Denkbild in the following way: "the philosophical miniatures of the Denkbild can be understood as conceptual engagements with the aesthetic and as aesthetic engagements with the conceptual, hovering between philosophical critique and aesthetic production" (2). As the now conventional grouping of Walter Benjamin, Siegfried Kracauer, Ernst Bloch, and Adorno suggests, the preference for the Denkbild belongs to a particular generation and cohort of writers who all developed or at least indicated philosophical arguments for this form (Moretti 20 22 ), such as the abandonment of the will to a system and of the procedures of conventional theoretical and logical analysis. In this paper, I do not want to deny the extraordinary importance of this context, but I propose a previously neglected framework for understanding the work that $\mathrm{Mi}$ nima Moralia performs. While Adorno's text cannot be exclusively defined as a Ratgeber (advice book), and while no text can be said to belong fully to any particular genre (Derrida), I argue that reading Minima Moralia for advice will illuminate a central structuring dynamic of the text. 
3. Quotations of Adorno's Minima Moralia in English are from the edition edited by Jephcott. German quotations are from Tiedemann's edition.

4. Krumrey counts the number of titles published in the genre of advice literature ("Anstand- und Manierenbücher") in Germany over the course of nine decades. While he admits that he might have missed or miscategorized some titles, he maintains that the general trends remain evident ("eindeutig belegbar" [27]). The figures for the last four decades that he covers are the following: 1930-40, 54 titles; 1940-50, 42 titles; 1950-60, 128 titles; 1960-70, 78 titles.

5 . The recipient of advice is imagined to be sufficiently resourceful to achieve goals independently, provided that he or she follows the counsel made available. Advice thus differs from education: while the latter is supposed to lead the subject from a state of immaturity and dependence to adulthood, professional responsibility, and citizenship, the former is given to an already self-reliant person, for whom an entire educational program would seem paternalistic. The advisee is never simply a vessel, and asking for advice can be conceived of as a forward-looking act or mode of self-assertion. One can strive to become a "highly effective mentee," good at building relationships, good at discriminating between advisers, and good at asking the right questions (Casnocha). In this context, Freudian psychoanalysis offers a contrast. The psychoanalyst must as a rule abstain from concrete advice on life matters, for in the eyes of the patient whose problem is a vulnerable ego, the dispensation of advice would appear as paternal guidance and hence perpetuate the condition that the therapy hopes to address (Freud 34). One should not give advice to people who are not already independent enough to discard it-that is, to people who cannot distinguish between advice and command (Arendt 123). Even the strongest form of advice, advice you would be foolish not to follow, must in principle be open to rejection.

6. In contrast, Jürgen Habermas also considers the twin dangers that confront the intellectual-assimilation to an institutional reality and escape into the (compromised) sanctuary of pure thought and art-but believes in a position that transcends these nonalternatives, represented in Germany by the poet Heinrich Heine $(42,46)$. Adorno clearly has no interest in conjuring up solutions in Minima Moralia.

7. If anything, some of Adorno's aphorisms detail how the liberal rhetoric of self-assertion cancels out the individuality that it insists on. As Adorno's contemporary Dale Carnegie demonstrated in his famous success manual, one wins friends and influences people by assimilating completely to the demands of one's environment (116). You get ahead by getting along (McGee 36). Plans for individual achievement are at one with a world structured by relations of domination, for the promised influence of the individual over others depends both on self-mastery as a governed object and on conformity with the logic of the extant social world.

8. Axel Honneth has demonstrated how Adorno and Max Horkheimer use rhetoric as the only means to push the reader toward philosophical insight in The Dialectic of Enlightenment. Formulations such as "culture industry" combine concepts previously thought of as oppositional in a way that may have been jarring to Adorno and Horkheimer's audience. Such rhetorical juxtapositions, Honneth claims, do work that coherent argumentation alone cannot accomplish (123).

\section{Works Cited}

Adorno, Theodor W. Critical Models: Interventions and Catchwords. Trans. Henry W. Pickford. New York: Columbia UP, 1998. Print.

- Einleitung in die Soziologie. 1968. Ed. Christoph Gödde. Frankfurt am Main: Suhrkamp, 1993. Print.

_. Minima Moralia: Reflections from Damaged Life. Trans. E. F. N. Jephcott. London: New Left, 1974. Print. - Minima Moralia: Reflexionen aus dem beschädigten Leben. Ed. Rolf Tiedemann. Frankfurt am Main: Suhrkamp, 2003. Print.

- Philosophische Elemente einer Theorie der Gesellschaft. 1964. Ed. Tobias ten Brink and Marc Phillip Nogueira. Frankfurt am Main: Suhrkamp, 2008. Print. . "Sociology and Psychology, Part II.” Trans. Irving N. Wohlfahrt. New Left Review 47 (1968): 79-97. Print.

. The Stars down to Earth: The Los Angeles Times Astrology Column: A Study in Secondary Superstition. Ed. Susan Buck-Morss and Rolf Tiedemann. Frankfurt am Main: Suhrkamp, 1975. Print. Vol. 2 of Soziologische Schriften.

Arato, Andrew, and Jean L. Cohen. Civil Society and Political Theory. Cambridge: MIT P, 1992. Print.

Arendt, Hannah. Between Past and Future: Eight Exercises in Political Thought. 1961. London: Penguin, 1993. Print.

Benjamin, Jessica. “The End of Internalization.” Telos 32 (1977): 42-64. Print.

Bergsma, Ad. “Do Self-Help Books Help?” Journal of Happiness Studies 9.3 (2008): 341-60. Print.

Bernard, Andreas. "Umtausch nicht gestattet." Minima Moralia neu gelesen. Ed. Bernard and Ulrich Raulff. Frankfurt am Main: Suhrkamp, 2003. 15-19. Print.

Bernstein, J. M. Adorno: Disenchantment and Ethics. Cambridge: Cambridge UP, 2001. Print.

. The Fate of Art: Aesthetic Alienation from Kant to Derrida and Adorno. Cambridge: Polity, 1992. Print.

Bobbio, Norberto. Liberalism and Democracy. Trans. Martin Ryle and Kate Soper. London: Verso, 1990. Print.

Bull, Malcolm. "The Limits of Multitude." New Left Review 35 (2005): 19-39. Print. 
Carnegie, Dale. How to Win Friends and Influence People. 1936. Ed. Dorothy Carnegie. New York: Simon, 1981. Print.

Casnocha, Ben. "Six Habits of Highly Effective Mentees." Ben Casnocha: A Blog about Entrepreneurship, Books, Current Affairs, and Intellectual Life. 15 Apr. 2008. Web. 5 Nov. 2010.

Demirovic, Alex. Der nonkonformistische Intellektuelle: Die Entwicklung der Kritischen Theorie zur Frankfurter Schule. Frankfurt am Main: Suhrkamp, 1999. Print.

Derrida, Jacques. “The Law of Genre.” Trans. Avital Ronell. Acts of Literature. Ed. Derek Attridge. London: Routledge, 1992. 221-52. Print.

Elster, Jon. "Belief, Bias, and Ideology." Ideology. Ed. Terry Eagleton. London: Longman, 1994. 238-59. Print.

Freud, Sigmund. Abriß der Psychoanalyse. Frankfurt am Main: Fischer, 1953. Print.

Fuller, Steve. The Intellectual. Cambridge: Icon, 2005. Print.

Habermas, Jürgen. Eine Art Schadensabwicklung: Kleine politische Schriften VI. Frankfurt am Main: Suhrkamp, 1987. Print.

Hardt, Michael. "The Withering of Civil Society." Social Text 14.4 (1995): 27-44. Print.

Hegel, G. W. F. Grundlinien der Philosophie des Rechts oder Naturrecht und Staatswissenschaft im Grundrisse. Frankfurt am Main: Suhrkamp, 1986. Print. Vol. 7 of Werke.

Helmstetter, Rudolf. "Guter Rat ist (un)modern: Die Ratlosigkeit der Moderne und ihre Ratgeber." Konzepte der Moderne. Ed. Gerhart von Graevenitz. Stuttgart: Metzler, 1999. 147-72. Print.

Hirschman, Albert O. The Passions and the Interests: Political Arguments for Capitalism before Its Triumph. Princeton: Princeton UP, 1977. Print.

Honneth, Axel. "The Possibility of a Disclosing Critique of Society: The Dialectic of Enlightenment in Light of Current Debates in Social Criticism." Trans. John Farrell and Siobhan Kattago. Constellations 7.1 (2000): 116-27. Print.

Jaeggi, Rahel. “'Kein Einzelner vermag etwas dagegen': Adornos Minima Moralia als Kritik von Lebensformen." Dialektik der Freiheit: Frankfurter AdornoKonferenz, 2003. Ed. Axel Honneth. Frankfurt am Main: Suhrkamp, 2005. 115-41. Print.

Jarvis, Simon. Adorno: A Critical Introduction. New York: Routledge, 1998. Print.

Krumrey, Horst-Volker. Entwicklungsstrukturen von Verhaltensstandarden: Eine soziologische Prozeßanalyse deutscher Anstands- und Manierenbücher von 1870 bis 1970. Frankfurt am Main: Suhrkamp, 1984. Print.

Lizza, Ryan. “The Mission.” New Yorker 29 Oct. 2007: 41-45. Print.
Luhmann, Niklas. Soziologische Aufklärung: Aufsätze zur Theorie sozialer Systeme. Köln: Westdeutscher, 1970. Print.

McGee, Micki. Self-Help, Inc.: Makeover Culture in American Life. Oxford: Oxford UP, 2005. Print.

Moretti, Franco. Graphs, Maps, Trees: Abstract Models for Literary History. London: Verso, 2005. Print.

Patterson, Kerry, et al. Influencer: The Power to Change Anything. New York: McGraw, 2007. Print.

Pfau, Thomas. "Beyond Liberal Utopia: Freedom as the Problem of Modernity." European Romantic Review 19.2 (2008): 83-103. Print.

Pippin, Robert B. The Persistence of Subjectivity: On the Kantian Aftermath. Cambridge: Cambridge UP, 2005. Print.

Postone, Moshie. Time, Labor, and Social Domination: A Reinterpetation of Marx's Critical Theory. Cambridge: Cambridge UP, 1993. Print.

Puchner, Martin. Poetry of the Revolution: Marx, Manifestos, and the Avantgardes. Princeton: Princeton UP, 2006. Print.

Raulff, Ulrich. "Die Minima Moralia nach fünfzig Jahren: Ein philosophisches Volksbuch im Spiegel seiner frühen Kritik." Minima Moralia neu gelesen. Ed. Andreas Bernard and Raulff. Frankfurt am Main: Suhrkamp, 2003. 122-31. Print.

Richter, Gerhard. Thought-Images: Frankfurt School Writers' Reflections from Damaged Life. Stanford: Stanford UP, 2007. Print.

Riedel, Manfred. Studien zu Hegels Rechtsphilosophie. Frankfurt am Main: Suhrkamp, 1969. Print.

Rimke, Heidi Marie. "Governing Citizens through Self-Help Literature.” Cultural Studies 14.1 (2000): 61-78. Print.

Robbins, Bruce. Upward Mobility and the Common Good: Toward a Literary History of the Welfare State. Princeton: Princeton UP, 2007. Print.

Rosen, Michael. On Voluntary Servitude: False Consciousness and the Theory of Ideology. Cambridge: Harvard UP, 1996. Print.

Schildt, Axel. "Bürgerliche Gesellschaft und kleinbürgerliche Geborgenheit: Zur Mentalität im westdeutschen Wiederaufbau der 50er Jahre." Kleinbürger: Zur Kulturgeschichte des begrentzten Bewußtseins. Ed. Thomas Althaus. Tübingen: Attempto, 2001. 295-312. Print.

Schweppenhäuser, Gerhard. Theodor W. Adorno: An Introduction. Trans. James Rolleston. Durham: Duke UP, 2009. Print.

Vogl, Joseph. Kalkül und Leidenschaft: Poetik des ökonomischen Menschen. Zürich: Diaphanes, 2004. Print.

Wagner, Peter. "Versuch, das Endspiel zu verstehen: Kapitalismusanalyse als Gesellschaftstheorie." Dialektik der Freiheit: Frankfurter Adorno-Konferenz, 2003. Ed. Axel Honneth. Frankfurt am Main: Suhrkamp, 2005. 205-34. Print. 